\title{
The Development and Validation of a Basic Psychological Needs Scale for Children (BPNS-C)
}

\author{
Mi Na Kwon ${ }^{1}$, Jinsuk Lee ${ }^{2}$ \\ Ph. D., Department of Child Studies, Chonbuk National University, Jeonju, Korea ${ }^{1}$ \\ Professor, Department of Child Studies, Chonbuk National University, Jeonju, Korea \\ 아동용 기본심리욕구 척도 개발 및 타당화 \\ 권미나 ${ }^{1}$, 이진숙 ${ }^{2}$ \\ 전북대학교 아동학과 박사졸업, 전북대학교 아동학과 교수 ${ }^{2}$
}

Objectives: This study aims to develop and validate a basic psychological needs satisfaction and frustration scale for school-aged children.

Methods: A total of 49 preliminary questions were extracted using the Delphi method. These questions were first composed through pilot studies and a group interview with children. The present study was conducted among students in 4th to 6th grade in elementary school. The data of a total of 455 participants were analyzed through exploratory factor analysis, confirmatory factor analysis, and correlations.

Results: The results of factor analysis identified a total of 33 questions constituting 6 factors (autonomy need satisfaction, competence need satisfaction, relationship need satisfaction, autonomy need frustration, competence need frustration, and relationship need frustration). This scale showed a significant correlation with life satisfaction, school adjustment, aggression, and depression variables, which verified the convergent validity. A comparison of the means of basic psychological needs of clinical and nonclinical children showed a significant difference, verifying the discriminant validity of the scale. Finally, the results of calculating internal consistency coefficient and split-halves reliability coefficient showed that the scale was reliable.

Conclusions: This study is meaningful, in that it developed a reliable and valid scale to measure the satisfaction and frustration of basic psychological needs, reflecting children's actual experiences and developmental characteristics.

Keywords: basic psychological needs, children, scale development, validation

\section{Introduction}

아동기는 가정 중심의 생활에서 학교라는 새로운 환경으로 생 활환경이 확장되고 다양한 경험을 통해 발달이 이루어지는 시 기이다. 이 시기의 아동은 부모의 영향에서 벗어나 학교와 또 래 관계라는 외부 상황에 적응하기 위해 자신의 행동과 감정

Corresponding Author: Jinsuk, Lee, Professor, Department of Child Studies, Chonbuk National University, 567 Baekje-daero, Deokjin-gu, Jeollabuk-do, Korea

E-mail: jslee0820@jbnu.ac.kr
을 적절히 통제할 수 있는 능력이 요구된다. 자신에게 주어진 환경에 적응한 아동은 학습 상황에서 내재동기가 향상되고 성 장 과정에서 발생되는 심리적인 어려움과 스트레스에 잘 대 처할 수 있는 반면, 자신의 행동과 감정을 통제하지 못하고 자 신이 속한 환경에 적응하지 못한 아동은 공격성, 학교 부적응 및 우울, 불안 등의 문제가 발생하게 된다(S. A. Lee, 2016; Sim,

(C)The Korean Association of Child Studies

This is an Open Access article distributed under the terms of the Creative Commons Attribution Non-Commercial License (http:// creativecommons.org/licenses/by-nc/4.0) which permits unrestricted noncommercial use, distribution, and reproduction in any medium, provided the original work is properly cited. 
2016). 이처럼 아동이 변화하는 환경에 잘 적응하고, 발달과업 을 습득하기 위해서는 기본심리욕구가 만족되어야 한다.

기본심리욕구란 인간이 생득적으로 가지고 태어나는 욕 구이며, 심리적인 성장과 적응 및 만족감을 위해 요구되는 필 수 요인으로 자율성, 유능성, 관계성의 욕구가 포함되어 있다 (Deci \& Ryan, 2000). 자율성이란 개인이 자유의지를 가지고 스스로 선택하고 행동하는 것이며, 유능성이란 자신이 속한 환경과 지속적인 상호작용을 통해 자신의 능력을 숙달하고 자신감과 효능감을 느끼는 것이다. 마지막으로 관계성은 다 른 사람들과 사회적 환경에 소속되어 있으며 다른 사람으로 부터 지지와 돌봄 받는 느낌으로 설명된다(Deci \& Ryan, 2000;

Gagné \& Deci, 2005).

개인이 속한 사회 환경 안에서 기본심리욕구 만족은 내재 동기를 향상시키고, 삶의 만족과 행복감의 수준이 증진되는 반면 욕구좌절은 외부의 압력과 보상에 의해 행동이 유발되어 우울·불안, 공격성과 같은 문제행동들이 발생하게 된다(Deci \& Ryan, 2000; Vansteenkiste, Ryan, \& Deci, 2008). 많은 국내. 외 연구들을 통해 기본심리욕구 만족은 주관적 안녕감, 활 력 및 긍정정서(Adie, Duda, \& Ntoumanis, 2012; Bartholomew, Ntoumanis, Ryan, Bosch, \& Thøgersen-Ntoumani, 2011; Eryilmaz, 2012; S.-H. Kwon \& Kim, 2014)와 정적상관이 있는 것으로 밝혀졌으며, 학교적응, 학업성취(S. Cho, 2014; Heo \& Oh, 2014; A. Kim \& Lee, 2008; S. Y. Lee, 2012; Song, Ahn, \& Jung, 2014; Tian, Chen, \& Huebner, 2014)와의 관련성도 입증 되고 있다. 웰빙이란, 한 문장으로 간략하게 정의내리기는 어 려우나 '건강하고, 안락하고, 만족하는 삶을 살아가고자 하는 의미로 행복, 삶의 만족, 질병이 없는 상태'로 정의되고 있다 (S.-S. Kim, 2006). 선행연구를 통해 기본심리욕구 만족은 심신 의 건강과 편안함을 의미하는 웰빙 지표인 활력, 행복감 및 삶 의 만족 등과의 관계가 경험적으로 지지되어 왔다. 이러한 연 구들은 기본심리욕구 만족이 인간의 심리성장과 적응에 중요 한 요인임을 뒷받침해주는 결과이다. 특히 아동기의 기본심리 욕구 만족은 아동의 사회 - 정서 발달 및 적응에 영향을 주고, 행복감을 경험하게 하며 이 시기의 경험은 이후 삶에 지속적 인 영향을 미치므로 아동기의 기본심리욕구 만족은 매우 중요 하다고 볼 수 있다.

한편, 최근에는 기본심리욕구 만족과 좌절은 연속선상의 개념이 아니라 독립된 구성 개념이며, 웰빙(well-being)과 일빙 (ill-being)에 서로 다른 결과를 초래한다는 견해가 제기되고 있 다(Bartholomew, Ntoumanis, Ryan, Bosch et al., 2011; Chen et al., 2015). 욕구좌절은 자신의 욕구가 타인의 의해서 훼손되거
나 차단되었다고 지각될 때 나타나는 감정으로, 욕구만족 수 준이 낮은 것과는 다른 의미이다(Bartholomewet et al., 2011). 예컨대, 자율성의 욕구만족이 낮다는 것은 자기결정성 수준이 낮음을 의미하지만, 자율성의 욕구좌절은 다른 사람으로부터 통제와 강압을 받는 느낌이다. 관계성의 욕구만족이 낮다는 것은 타인과 친밀한 경험이 많지 않다는 것을 의미하는 반면, 관계성의 욕구좌절은 소외감과 외로움을 경험하는 것이라고 볼 수 있다(Chen et al., 2015; Vansteenkiste \& Ryan, 2013).

일빙이란 웰빙과 반대되는 개념으로, 심리적인 고통을 경 험하고 있으며, 사회적 규범으로 벗어나 부적응적인 상태를 보이는 것이다(Moon et al., 2015). 기존연구는 욕구만족 척도 를 가지고 욕구만족이 낮은 상태를 좌절로 간주하여 우울 및 불안, 공격성 등 신체적 · 정신적인 어려움을 나타내는 일빙 과의 관계를 예측하였으나, 낮은 욕구만족과 일빙 간에 일관 성 있는 결과가 보고되지 않았다. 이에 일부 연구자들은 욕구 만족 척도의 문항들이 긍정문으로 서술되어 있어 일빙의 예 측 도구로 사용하는 것은 문제가 있을 수 있다고 주장하면서 욕구좌절 척도를 개발하고, 이를 실증적으로 지지하는 연구 결과들을 보고하였다(Bartholomew et al., 2011; Bartholomew, Ntoumanis, Ryan, Bosch et al., 2011). 이후 Chen 등(2015)은 기 본심리욕구 만족과 좌절을 모두 측정할 수 있는 도구를 개발 하였으며, 기본심리욕구 좌절이 일빙에 독자적인 영향을 미친 다는 연구결과들(Bartholomew et al., 2011; Chen et al., 2015)도 보고되고 있다. 요컨대 기본심리욕구 만족과 좌절은 서로 구 별되는 개념이며, 기존 기본심리욕구 만족 척도로 욕구좌절을 측정하는 것은 무리가 있다. 따라서 아동의 기본심리욕구 만 족뿐 아니라 좌절을 별도로 측정할 수 있는 도구가 개발된다 면, 기본심리욕구의 만족 및 좌절이 미치는 긍정적 혹은 부정 적인 결과를 연구하는데 유용할 것이다.

또한 기본심리욕구에 관한 국내연구의 경우 성인 및 청소 년에 비해 아동을 대상으로 한 연구는 매우 미비한 상황이다. 이는 아동용 기본심리욕구 척도의 부족 및 기존 척도의 문제 점에 기인한 것으로 보인다. 아동용 기본심리욕구 척도가 개 발되어 있지만 어머니-자녀라는 특정 관계(G.-Y. Jeong \& Shin, 2010), 체육수업 및 신체활동과 같은 특정 상황(M.-H. Choi, 2009; I.-S. Kim, 2009)에 한정되어 있다. 또한 척도를 번안한 연구(H.-E. Lee, 2012)에서는 충분한 타당도 검증이 이루어지 지 않았다. M. Lee (2008)의 척도는 청소년용 척도로 자율성과 유능성의 상관이 높아 두 요인을 독립된 요인으로 보기 어려 우므로 이를 보완할 필요가 있다.

뿐만 아니라 기존 척도는 청소년과 성인을 대상으로 개발 
및 타당화 되었기 때문에 아동기의 발달적 특성이 반영되지 못하였다. 아동기는 Erikson (1982)의 심리사회 발달 중 근면 성 대 열등감의 시기로, 학업과제를 수행하는 과정에서 근면 성, 유능감 을 경험하며, 가정으로부터 벗어나 또래집단에 소 속되는 과정에서 관계성이 확장된다(O. Jeong, 2016). 그러나 성취를 느끼지 못하고 실패하면 열등감이 생기고 부정적 자아 가 형성될 수 있다. 이처럼 아동기는 아동기만의 독특한 발달 특성을 보이기 때문에 아동용 척도를 개발하기 위해서는 아동 의 발달 특성이 반영될 필요가 있다.

한편, 한국사회와 서구사회의 사회문화적인 환경의 차이는 국외 척도를 번안하여 그대로 사용하기보다 한국 사회의 문화 적 특성을 고려할 필요가 있음을 말해준다. 서구의 경우 가족 구성원의 자율성과 독립성을 강조하는 반면 한국은 혈연중심 의 수직적인 가족관계로 가족의 유대와 조화를 강조하여 상호 의존적인 특징을 보인다(H. Kim, 2015). 학교환경에서도 서구 의 경우 학생들의 자율성, 창의성, 개성을 강조하는 반면 한국 은 경쟁과 입시위주의 학교환경으로 인지나 학업성취를 강조 하는 경향이 있다(J. Kwon, 2016). 이처럼 우리나라는 가정과 학교환경에서 서구와는 상이한 특성을 보이므로, 우리나라 아 동에게 적합한 기본심리욕구 척도의 개발이 요구된다.

이상의 내용을 통해 기존에 개발된 아동용 척도는 기본심 리욕구 만족은 측정하고 있으나 좌절은 포함하지 않으며, 특 정 상황이나 특정 관계에 한정되고, 아동의 발달적 특성 및 문 화적 상황에 대한 고려가 충분하지 못하였음을 알 수 있다. 따 라서 본 연구는 학령기 아동을 대상으로 기본심리욕구의 만족 뿐 아니라 좌절을 포함하며, 아동의 발달적 특성과 한국의 문 화적 특성이 고려된 아동용 기본심리욕구 척도를 개발하고자 한다.

본 연구는 아동용 기본심리욕구 척도 개발 및 타당화를 위 해 국내.외 기본심리욕구 척도개발 연구와 각 하위요인과 관 련된 선행연구들을 고찰하고, 개방형 질문지를 통한 집단면 접을 실시하여 예비문항을 개발한 후 본조사를 통해 타당도 와 신뢰도를 살펴보고자 한다. 기본심리욕구의 만족도가 높 을 때 삶의 만족(Eryilmaz, 2012; M. N. Kwon \& Lee, 2015; S.H. Kwon \& Kim, 2014; Milyavskaya \& Koestner, 2011)과 학교 적응(Heo \& Oh, 2014; A. Kim \& Lee, 2008; S. Y. Lee, 2012) 수 준은 높아지고, 반대로 기본심리욕구의 좌절수준이 높을 때 우울과 같은 일빙(Chen et al., 2015; Nishimura \& Suzuki, 2016; Vansteenkiste \& Ryan, 2013)이 높아진다는 선행연구를 통해 삶 의 만족, 학교적응, 공격성, 우울의 변인을 선정하여 수렴타당 도를 살펴볼 것이다. 또한 기본심리욕구가 좌절될 때 우울, 불
안 및 공격성과 같은 문제가 나타날 수 있으므로 비 임상아동 집단과 임상아동 집단의 기본심리욕구 만족과 좌절의 평균점 수를 비교하여 변별타당도를 검증하고자 한다. 타당도를 살펴 본 후 본 연구에서 개발된 척도의 신뢰도를 알아보기 위해 내 적합치도와 반분신뢰도를 실시할 것이다. 이러한 과정을 통해 아동의 실제 경험과 발달적 특성이 반영되고, 기본심리욕구 만족과 좌절을 모두 측정할 수 있는 타당하고 신뢰로운 척도 를 개발하고자 한다. 본 연구를 통하여 아동의 기본심리욕구 만족과 좌절에 관련된 기초연구 및 기본심리욕구 향상을 위한 프로그램 효과를 검증할 뿐 만 아니라 기본심리욕구가 좌절된 아동을 조기에 선별하여 개입하는 데에도 활용될 수 있을 것 으로 기대된다.

\section{연구문제 1}

아동용 기본심리욕구 척도의 구성요인은 어떠한가?

\section{연구문제 2}

아동용 기본심리욕구 척도의 타당도는 어떠한가?

\section{연구문제 3}

아동용 기본심리욕구 척도의 신뢰도는 어떠한가?

\section{Methods}

\section{연구절차}

아동용 기본심리욕구 척도는 2 단계에 걸쳐 개발 및 타당화 되 었다. 1 단계는 아동용 기본심리욕구 척도의 예비구인 및 예비 문항 선정단계이다. 예비구인 및 예비문항을 개발하기 위해 아동을 대상으로 집단면접을 실시하고, 관련 선행연구를 고찰 하여 예비문항을 구성한 후 내용타당도를 검증하였다. 2단계 는 본조사 및 타당도, 신뢰도 검증 단계이다. 초등 4-6학년 아 동을 대상으로 본조사를 실시한 후 탐색적 요인분석과 확인적 요인분석을 통해 구성타당도를 검증하였다. 구성타당도 검증 을 통해 아동용 기본심리욕구 척도의 하위요인 및 최종 문항 이 선정되었으며, 아동용 기본심리욕구 척도의 최종 문항으로 타당도와 신뢰도를 검증하였다. 2단계에 걸쳐 진행된 연구절 차는 전북대학교 생명연구윤리위원의 승인을 받아 진행하였 다(IRB 승인번호 JBNU 2017-01-010-005). 
예비문항 개발

\section{기본심리욕구 관련 선행연구 고찰과 집단면접 및 예비문항 개발}

아동용 기본심리욕구 척도의 예비구인 및 예비문항 선정을 위해 선행연구 고찰, 집단면접 및 예비문항 개발, 내용타당도 검증을 실시하였다. 먼저 기존 기본심리욕구와 관련된 국내 외 선행연구(I. Choi, 2007; K.-H. Kim, 2002; M.-K. Lee \& Kim, 2011; S. A. Lee, 2016; Ryan \& Deci, 2000)고찰을 통해 기본심 리욕구의 하위요인과 그 특성에 대해 확인하였다.

다음으로 본 연구에서는 초등학교 4-5학년 아동 23 명을 5 그룹으로 나누어 기본심리욕구와 관련된 집단면접을 진행하 였다. 집단면접 실시기간은 2018년 1월 학년말로 이 시기의 6 학년 아동은 중학교를 준비하는 과정에 있어 연구대상에서 제 외되었다. 집단면접 대상의 인구학적 특성을 살펴보면 남학생 이 12명(52.17\%), 여학생이 11명(47.83\%)이었으며, 학년별로 는 4학년 13명(56.52\%), 5학년 10명(43.48\%)이었다. 집단면접 은 연구자가 사전에 준비한 개방형 질문을 제시하고 연구대 상자들이 질문에 대한 자신의 생각과 경험을 자유롭게 답하는 형식으로 진행하였다. 질문의 내용으로는 아동들이 생활하면 서 즐겁고 기분 좋았었던 경험과 힘들고 속상했던 경험이다. 이는 기본심리욕구가 만족될 때 웰빙을 경험하고 반대로 각각 의 욕구가 좌절될 때 일빙을 경험한다는 기본심리욕구 이론에 근거한 것이다. 집단면접에 대한 자료수집은 면접과정을 녹음 하는 방법과 현장노트 기록방법을 사용하였다. 5그룹 모두 연 구자가 직접 집단면접을 진행하였으며, 연구보조자 1 인(아동 학과 석사과정)이 면접과정 녹음과 현장노트를 기록하였다.

집단면접 자료를 분석하기 위해 녹음된 면접 내용과 현장노 트 기록을 전사하였다. 본 연구는 기본심리욕구에 대해 알아보 는 연구로 전사된 내용 중 밥 먹을 때, 잠잘 때 등과 같은 신체 및 물리적인 욕구에 해당하는 내용은 제외하였으며, 심리와 관 련된 내용만을 분석자료로 사용하였다. 전사된 자료는 연구자 와 아동상담 전공 박사 1 인이 함께 읽어 나가며 비슷한 내용끼 리 분류 및 범주화한 후, 아동학 교수와 함께 분류한 내용과 범 주가 적절한지 검토하고 최종 수정하였다. 마지막으로 범주화 한 자료에 예비구인의 명칭을 정하고, 예비구인에 포함된 아동 들의 경험을 예비문항으로 개발하였다. 집단면접을 통해 나타 난 아동용 기본심리욕구 척도의 예비구인은 이론과 마찬가지 로 자율성의 욕구만족, 자율성의 욕구좌절, 유능성의 욕구만 족, 유능성의 욕구좌절, 관계성의 욕구만족, 관계성의 욕구좌 절 총 6 개로 나타났으며 44 개의 예비문항이 개발되었다.

아동대상 집단면접을 통해 아동용 기본심리욕구 척도의 예
비문항을 개발한 후 각각의 예비구인과 관련된 선행연구를 참 고하여 추가적으로 필요한 문항을 구성하였다. 선행연구를 고 찰하여 아동의 기본심리욕구 만족과 좌절에 해당하는 문항 풀 을 만든 후 공통적인 문항들을 선별하여 최종 문항(36문항)을 구성하였다. 그다음 집단면접으로 개발된 문항(44문항)과 선 행연구에서 추출한 문항을 비교하는 과정에서 개발된 문항의 진술문을 수정·보완하고 중복되거나 유사한 문항은 삭제하였 다. 그 결과 총 62 개의 최종 예비문항이 구성되었다.

내용타당도 검증 예비문항이 아동의 기본심리욕구를 측정 하기에 적합한지 알아보기 위해 델파이 조사를 활용하여 내용 타당도를 검증하였다. 본 연구에서는 10 명의 전문가(아동학 교수 1 명, 석·박사 이상의 아동상담 전문가 5 명, 경력 8년 이상 의 초등학교 교사 4 명)에게 2 차에 걸쳐 델파이 조사를 실시하 였다. 1 차 델파이 조사는 전문가 패널에게 62 개의 예비문항으 로 구성된 아동용 기본심리욕구 척도 질문지를 의뢰한 후 5점 Likert척도로 응답하도록 하였다. 또한 통합, 삭제, 수정이 필요 하다고 판단되는 문항에 대해 기타 의견을 작성하도록 하였다.

1 차 델파이 조사 후 자료를 분석한 결과 평균값이 3.5 이하, CVR값이 .60이하, 합의도가 .75이하, 수렴도가 .50이상인 문 항은 수정하거나 삭제하였다. 결과적으로 1 차 델파이 조사를 통해 62 개의 예비문항 중 16 문항이 삭제, 7 문항이 수정, 3 문항 이 추가되어 총 49 문항이 추출되었다. 1 차 델파이 조사 결과 를 반영하여 연구자가 수정한 문항들에 대한 타당성을 살펴보 기 위해 2 차 델파이 조사를 실시하였다. 2 차 델파이 조사 역시 1 차 델파이 조사와 마찬가지로 평균, CVR, 합의도, 수렴도를 산출하였으며, 모든 문항에서 기준 값을 만족시키는 것으로 나타나 1 차 델파이 조사 결과로 산출된 49 문항을 최종 예비문 항으로 선정하였다.

\section{본 연구}

본 연구를 위한 조사는 초등학교 4-6학년 아동을 대상으로 실 시하였다. 본조사 자료를 바탕으로 탐색적 요인분석 과정을 통해 구성요인과 최종 문항을 산출하였으며, 확인적 요인분석 과정을 통해 요인구조의 적합성을 확인하였다. 또한 선행연구 를 토대로 기본심리욕구가 삶의 만족, 학교적응, 공격성, 우울 과 관련이 있을 것으로 가정하고, 변수 간의 상관관계를 산출 하여 수렴타당도를 검증하였으며, 임상아동 집단과 비 임상아 동 집단과의 기본심리욕구 만족 및 좌절의 평균점수를 비교 함으로써 변별타당도를 검증하였다. 마지막으로 본 연구에서 
개발된 척도의 신뢰도 검증을 위해 질문지 자료를 두 부분으 로 나누어 반분된 검사 점수들 간의 상관계수를 산출하여 유 사성을 살펴보는 반분신뢰도(Spearman-Brown)와 내적합치도 (Cronbach's $\alpha$ )를 산출하였다.

\section{연구대상}

전라도 소재 일곱 곳의 초등학교에 재학 중인 4-6학년 아동 670 명을 대상으로 척도 타당화를 위한 본조사를 실시하였다. 본조사 실시기간은 2018년 3월 30일부터 4월 20일까지 이다. 연구자는 해당학교의 학교장과 담임교사의 동의하에 쉬는시 간을 이용하여 아동들에게 본 연구의 목적과 내용에 대해 설 명한 후 연구참여를 원하는 아동에게 설명문과 동의서, 질문 지, 선물이 함께 동봉된 봉투를 나누어 주었다. 동의서와 설문 지를 받은 아동은 가정으로 가져가 부모(법적 대리인)로부터 동의를 얻은 후 개인적으로 설문지를 작성하여 담임교사에게 가져오도록 하였다. 총 670 부의 설문지를 배부하였으며 이 중 492부가 회수되어 $73.4 \%$ 의 회수율을 보였다. 회수한 질문지 중 문항이 누락되거나 불성실한 응답 자료 37 부를 제외한 총 455 (67.91\%)부를 최종 분석 자료로 사용하였다.

또한 아동용 기본심리욕구 척도의 변별타당도 조사는 임상 아동 34 명과 비 임상아동 34 명을 대상으로 하였다. 임상집단은 학교부적응, 정서문제, 부모·또래와의 갈등 등 심리적인 문제 로 상담을 의뢰받아 현재 학교, 복지관, 사설 상담센터에서 심리 상담을 받고 있는 아동이다. 비 임상아동 집단은 본조사를 통 해 기본심리욕구 만족. 좌절 평균(만족 $M=3.97$; 좌절 $M=2.03$ ) 을 구한 후 1 표준편차 이내의 아동을 선별하여 구성하였다. 두 집단의 인구학적 특성을 살펴보면 임상아동의 경우 남학생 19 명(55.9\%), 여학생 15명(44.1\%)이었으며, 4학년 13명(38.2\%), 5 학년 9명(26.5\%), 6학년 12명(35.4\%)이었다. 비 임상아동의 경우 에는 남학생, 여학생이 각각 17 명(50.0\%)이었으며, 4학년 13명 (38.2\%), 5학년 11명(32.4\%), 6학년 10명(29.4\%)이었다.

\section{연구도구}

\section{아동용 기본심리욕구}

아동용 기본심리욕구 척도 문항은 선행연구 고찰 및 집단면접 을 통해 개발되었으며, 2 차에 걸친 델파이 조사 결과를 반영하 여 최종 49 개의 예비문항이 구성되었다. 각 문항에 대한 응답 은 자기보고용 5점 Likert (전혀 그렇지 않다[1]에서 매우 그렇
다[5])척도에 응답하도록 되어있다.

삶의 만족

아동의 삶의 만족을 측정하기 위해 Huebner (1991)가 개발하 고 타당화한 만 8-18세 아동의 삶의 만족도 척도를 번안하여 사용하였다. 이 척도는 총 7문항으로 구성되어있으며, 문항의 예로는 "나는 내 삶이 좋다.", "나는 내 삶에 불만이 없다.", 등 이 있다. 본 척도는 5점 Likert (전혀 그렇지 않다[1]에서 매우 그렇다[5])척도로 점수가 높을수록 아동의 삶의 만족도가 높 음을 의미하며, 본 연구에서 산출한 Cronbach's $\alpha$ 값은 .79로 나 타났다.

\section{학교적응}

아동의 학교적응을 측정하기 위해 S. Cho (2014)가 초등학 생을 대상으로 개발한 학교적응 척도를 사용하였다. S. Cho (2014)의 학교적응 척도는 학업태도/규칙준수, 또래와의 관 계, 교사와의 관계, 학교 만족감 4 개의 하위 요인으로 구성되 어 있다. 이 중 학교만족감은 학교적응 상태를 포괄적으로 볼 수 있는 변인으로, 본 연구에서는 아동의 전반적인 학교적응 을 알아보기 위해 학교만족감 6 문항을 사용하였다. 문항의 예 로는 "나는 학교 가는 것이 즐겁다." 등이 있으며 4점 Likert (전 혀 그렇지 않다[1]에서 매우 그렇다[4])척도로, 점수가 높을 수록 학교 적응 수준이 높음을 의미한다. 본 연구에서 산출한 Cronbach's $\alpha$ 값은 .90으로 나타났다.

\section{공격성}

아동의 공격성을 측정하기 위해 B.-H. Cho와 $\operatorname{Lim}$ (2003)이 개 발한 공격성 척도를 수정 - 보완하여 사용하였다. 본 척도는 총 7문항으로 구성되어 있으며, 문항의 예로는 "작은 일에도 트집을 잡을 때가 있다.", "내가 원하는 일을 못하게 하면 따 지거나 덤빈다.”등이 있다. 공격성 척도는 4점 Likert (전혀 그 렇지 않다[1]에서 매우 그렇다[4])척도로 점수가 높을수록 아 동의 공격성 수준이 높음을 의미하며, 본 연구에서 산출한 Cronbach's $\alpha$ 값은 .83으로 나타났다.

$$
\text { 우울 }
$$

아동의 우울을 측정하기 위해 K. Kim, Kim과 Won (1984)이 개 
발한 정신진단검사 중 우울척도를 수정·보완한 National Youth Policy Institute (2015)의 척도를 사용하였다. 이는 총 10 문항으 로 구성되어 있으며, 문항의 예로는 "기운이 별로 없다.", "울 기를 잘 한다.” 등이 있다. 원 척도는 점수가 낮을수록 우울수 준이 높음을 의미하였으나 본 연구에서는 해석의 용이성을 위 해 4점 Likert (전혀 그렇지 않다[1]에서 매우 그렇다[4])척도로 역채점하여 사용하였다. 따라서 본 연구에서는 점수가 높을수 록 아동의 우울수준이 높음을 의미한다. 본 연구에서 산출한 Cronbach's $\alpha$ 값은 .87로 나타났다.

\section{자료분석}

본 연구에서 수집된 자료는 SPSS 22.0 (IBM Co., Armonk, NY) 프로그램과 AMOS 18.0 (IBM Co., Armonk, NY)프로그램을 이용하여 통계분석을 실시하였다. 첫째, 연구대상자의 인구 사회학적 배경을 파악하기 위해 빈도분석을 실시하였으며, 요 인분석 전 문항 정규성 검토를 산출하기 위해 기술통계분석 을 실시하였다. 둘째, 아동용 기본심리욕구 척도의 하위요인 을 검증하기 위해 탐색적 요인분석을 실시하고, 탐색적 요인 분석을 통해 얻어진 요인구조의 적합성을 파악하고자 확인적 요인분석을 실시하였다. 모델의 적합도 지수로 Turker-Lewis Index (TLI), Comparative Fit Index (CFI)를 사용하고 모형의 전 반적인 부합도를 평가하는 절대적 적합도 지수인 Root Mean Square Error of Approximation (RMSEA)를 사용하였다. 셋째, 요인분석을 통해 밝혀진 문항의 신뢰도 검증, 문항 제거 시 내 적합치도, 수렴타당도 검증에 사용되는 척도의 신뢰도를 알아 보기 위해 Cronbach's $\alpha$ 계수를 산출하였으며, 개발된 척도의 반분신뢰도 검증을 위해 Spearman-Brown계수를 산출하였다. 넷째, 본 연구에서 개발된 문항과 총점 간의 상관, 수렴타당도 검증을 위해 Pearson의 상관계수를 산출하였으며, 임상아동 집 단과 비 임상아동 집단의 기본심리욕구 평균을 비교하여 변별 타당도를 검증하기 위해 독립표본 $t$ 검증을 실시하였다.

\section{Results}

\section{아동용 기본심리욕구 척도의 구성요인}

\author{
탐색적 요인분석
}

탐색적 요인분석에 앞서 49 개의 예비문항에 대한 문항의 정
규성을 검토하였다. 그 결과 선행연구(Park, 2000)를 참고하여 평균이 2.0 미만이거나 왜도, 첨도의 절대값이 2.0 이상인 4 문 항(33번, 43번, 48번, 49번)을 삭제하였으며, 총 45개의 문항을 가지고 이후 분석을 실시하였다.

탐색적 요인분석 방법은 각 요인간의 상관관계를 가정하여 사각회전 방법을 이용하였으며, 요인추출 방법은 수집된 자료 를 표본으로 보는 최대우도법을 이용하였다. 먼저 전체문항 (45문항)에 대한 자료가 요인분석이 가능한지 알아보기 위하 여 $\mathrm{KMO}$ 의 표준 적합도와 Barttlett의 구형성 검정치를 검토하 였다. $\mathrm{KMO}$ 수치는 1 에 가까울수록 표본의 상관행렬이 요인 분석을 실시하기에 적합함을 의미하며, Bartlett 구형성 검정은 유의확률이 .50 이하이어야 모형이 적합하다고 볼 수 있다. 본 연구의 $\mathrm{KMO}$ 수치는 .90 으로 요인분석을 위한 문항으로 적합 하였으며, Bartlett 구형성 검정은 $p<.001$ 로 요인분석이 가능 한 공통요인이 있는 것으로 확인되었다.

전체 45 문항에 대한 요인분석결과 공통성이 .30이하로 나 타난 4 문항을 삭제한 후 41 문항으로 다시 요인분석을 실시하 였으며, 요인수가 6개일 때 이론적 모형에 부합하고, 양호한 문 항들로 추출되었다. 또한 각각의 요인에는 자율성의 욕구만족 과 좌절, 유능성의 욕구만족과 좌절, 관계성의 욕구만족과 좌 절 문항이 포함된 것으로 확인되었으며, 이는 기본심리욕구 이 론에 부합하는 결과이다. 따라서 본 연구는 기본심리욕구 이론 과 기본심리욕구 만족 및 좌절 척도개발 선행연구(Chen et al., 2015)를 바탕으로 전체문항(45문항)을 욕구만족 문항과 욕구 좌절 문항으로 각각 나누어 탐색적 요인분석을 재실시하였다.

먼저 기본심리욕구 만족 문항(25문항)에 대한 탐색적 요인 분석을 실시하였다. 요인분석 결과 공통성이 .30이하로 나타 난 6문항(4번, 8번, 9번, 10번, 32번, 38번)을 삭제한 후 19문항으 로 다시 요인분석을 실시하였다. 그 결과 요인부하량의 절대값 이 .35이하이거나 중복된 3문항(3번, 19번, 25번)이 삭제되었으 며, 총 3 요인 16 문항이 추출되었다. 요인1은 6 문항이며 자신에 대한 긍정적인 평가, 성취감, 자신감, 도전을 나타내는 내용으 로 기본심리욕구 중 ‘유능성의 욕구만족’으로 명명하였다. 요인 2 는 5 문항이며 가족과 친구 관계에서 친밀감을 느끼는 것과 관 련된 내용으로 기본심리욕구 중 '관계성의 욕구만족'이라고 명 명하였다. 요인3은 5 문항이며 관심 있는 것을 스스로 선택하고, 자신의 생각을 자유롭게 표현하는 것과 관계된 내용으로 기본 심리욕구 중 ‘자율성의 욕구만족'으로 명명하였다. 3 개 요인은 각각 전체변량이 $29.00 \%, 5.79 \%, 7.86 \%$ 를 설명하였으며, 전체 설명력을 의미하는 누적변량은 $42.65 \%$ 이었다(Table 1).

다음으로 기본심리욕구 좌절 문항(20문항)에 대한 탐색적 
Table 1

Exploratory Factor Analysis for the Satisfaction Items of the Basic Psychological Needs for Children

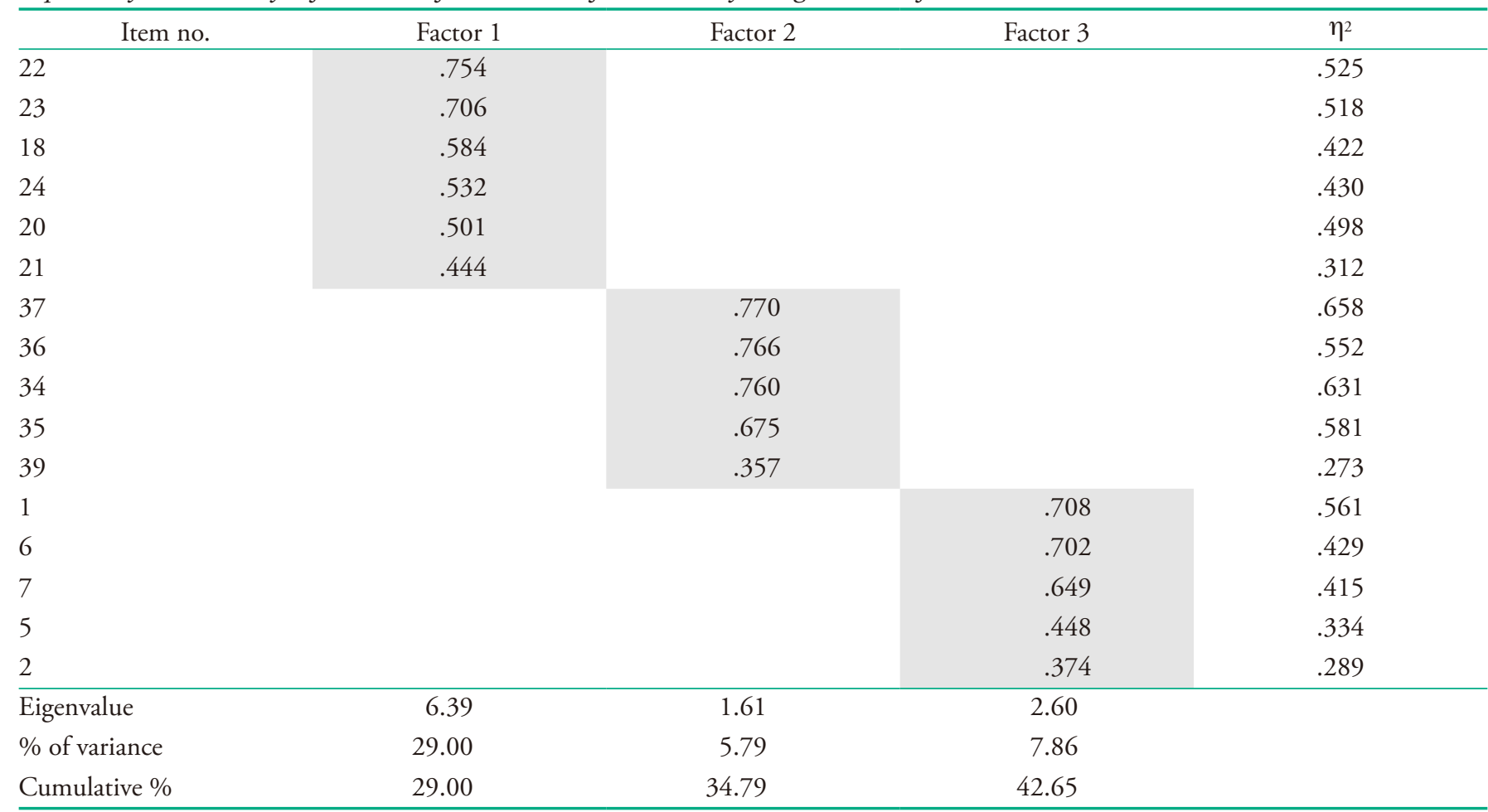

Note. $N=455$.

요인분석을 실시하였다. 요인분석 결과 공통성이 .30이하로 나타난 2문항(12번, 47번)을 삭제한 후 18문항으로 다시 요인 분석을 실시하였다. 그 결과 요인부하량의 절대값이 .35이하 이거나, 중복된 1문항(16번)이 삭제되어 총 3요인 17문항이 추 출되었다. 요인1은 6 문항이며 또래와의 관계에서 소외나 따 돌림을 나타내는 문항으로 기본심리욕구 중 '관계성의 욕구좌 절'로 명명하였다. 요인2는 6문항이며 일의 결과가 좋지 않아 느끼는 불쾌감이나 무력감 그리고 도전하지 않고 포기하는 내 용으로 기본심리욕구 중 ‘유능성의 욕구좌절’로 명명하였다. 요인3은 5문항이며 다른 사람의 강압에 의해 원치 않는 행동 을 하거나 하고 싶은 일을 하지 못하는 것으로 기본심리욕구 중 ‘자율성의 욕구좌절'이라고 명명하였다. 3 개 요인은 각각 전체변량이 $30.43 \%, 8.54 \%, 6.58 \%$ 를 설명하였으며, 전체 설 명력을 의미하는 누적변량은 $45.54 \%$ 이었다(Table 2).

\section{확인적 요인분석}

요인분석으로 산출된 기본심리욕구 만족과 좌절 총 33 문항에 대한 요인구조의 적합성을 확인하였다. 선행연구(Chen et al., 2015; J. H. Lee, 2016)에 근거하여 총 6요인(자율성의 욕구만
족, 유능성의 욕구만족, 관계성의 욕구만족, 자율성의 욕구좌 절, 유능성의 욕구좌절, 관계성의 욕구좌절)을 연구모형으로 가정하고, 위계모형(욕구만족과 좌절에 대해 자율성, 유능성, 관계성으로 구성된 2차 위계모형 6요인)을 경쟁모형으로 가 정하여 확인적 요인분석을 실시하였다. 두 모형에 대한 요인 구조의 적합도를 평가한 결과는 Table 3과 같다.

위 두 가지의 구조모형(연구모형, 경쟁모형)에 대한 요인구 조의 적합도를 평가하기 위해 $\chi^{2}$ 와 TLI, CFI, RMSEA 지수도 함께 확인하였다. TLI, CFI 지수의 경우 .90이상이면 좋은 적 합도, .90에 가까우면 양호한 적합도이며, RMSEA 지수의 경 우 .05이하이면 우수한 적합도, .08이하는 양호한 적합도로 해 석한다(J. Kim, Kim, \& Hong, 2012). 두 가지 구조모형의 적합 도를 비교해 보면 연구모형의 경우 $\chi^{2}$ 값은 $1279.832(d f=512)$, $\chi^{2} / d f$ 값은 $2.50, \mathrm{TLI}$ 는 $.85, \mathrm{CFI}$ 는 $.87, \mathrm{RMSEA}$ 는 .057의 지수를 보였다. 경쟁모형의 경우 $\chi^{2}$ 값은 $1360.202(d f=520), \chi^{2} / d f$ 값 은 2.62, TLI는 .83, CFI는 .85, RMSEA는 .060의 지수를 보였 다. 두 모형 모두 적합도 지수가 유사한 것으로 확인되었으나, 연구모형의 경우 $\chi^{2}$ 값이 더 작고, TLI, CFI 지수는 더 높게 나 타나 본 연구에서는 6요인인 연구모형을 채택하였다. 연구모 형의 적합도 지수 중 TLI 지수가 양호한 수준인 .90에 다소 미 
Table 2

Exploratory Factor Analysis for the Frustration Items of the Basic Psychological Needs for Children

\begin{tabular}{|c|c|c|c|c|}
\hline Item no. & Factor 1 & Factor 2 & Factor 3 & $\eta^{2}$ \\
\hline 41 & .894 & & & .714 \\
\hline 40 & .811 & & & .605 \\
\hline 46 & .795 & & & .680 \\
\hline 45 & .739 & & & .623 \\
\hline 44 & .684 & & & .460 \\
\hline 42 & .646 & & & .475 \\
\hline 31 & & .715 & & .499 \\
\hline 28 & & .710 & & .500 \\
\hline 29 & & .672 & & .397 \\
\hline 27 & & .623 & & .429 \\
\hline 26 & & .352 & & .311 \\
\hline 15 & & & .490 & .308 \\
\hline 17 & & & .391 & .305 \\
\hline Eigenvalue & 6.36 & 2.06 & 1.76 & \\
\hline$\%$ of variance & 30.43 & 8.54 & 6.58 & \\
\hline Cumulative \% & 30.43 & 38.97 & 45.54 & \\
\hline
\end{tabular}

Note. $N=455$.

Table 3

Fit Index of Basic Psychological Needs Scale for Children (BPNS-C)

\begin{tabular}{lcccccccc}
\hline Structural model & $\chi^{2}$ & $P$ & $d f$ & $\chi^{2} / d f$ & TLI & CFI & RMSEA & $\Delta \chi^{2}(d f)$ \\
\hline Research model & 1279.832 & .000 & 512 & 2.50 & .85 & .87 & .057 & $80.37(8)$ \\
Competitive model & 1360.202 & .000 & 520 & 2.62 & .83 & .85 & .060 & \\
\hline
\end{tabular}

Note. $N=455$.

치지 못하였지만 $\chi^{2}$ 값은 자유도 대비 2.5:1, 그리고 RMSEA는 .057로 수용할 만하다고 판단되었다. 연구모형에 대한 확인적 요인분석의 결과는 Figure 1 에 제시하였으며, 잠재변인과 측 정변인의 회귀계수 $(B)$, 표준화된 회귀계수 $(\beta)$, 표준오차 $(S E)$, Critical Ratio (C.R.)결과 통계적으로 유의한 것 $(p<.001)$ 으로 나타나 모든 측정변수가 잠재변수의 개념을 잘 반영하고 있는 것으로 해석할 수 있다.

탐색적 요인분석과 확인적 요인분석을 통해 최종 산출된 33 개 문항의 하위요인별 문항 제거 후 내적합치도, 문항과 하 위요인 간 상관을 살펴본 결과 문항 제거 후 내적합치도에서 각 하위요인 전체 내적합치도를 넘어서는 문항은 없었고, 문 항과 하위요인 간 상관은 .61 .86이으로 나타나 각 요인에 포 함된 문항들이 서로 동질적임이 입증되었다(Table 4).

지금까지 구성타당도, 신뢰도, 문항과 하위요인 간 상관을
확인하는 과정에서 최종적으로 구성된 33문항은 자율성의 욕 구만족 5문항, 유능성의 욕구만족 6 문항, 관계성의 욕구만족 5 문항, 자율성의 욕구좌절 5 문항, 유능성의 욕구좌절 6 문항, 관계성의 욕구좌절 6문항이며, 자세한 내용은 Table 5와 같다.

\section{아동용 기본심리욕구 척도의 타당화}

개발된 아동용 기본심리욕구 척도의 타당화는 수렴타당도와 변별타당도를 통해 검증하였다.

\section{수렴타당도 검증}

아동용 기본심리욕구 척도의 타당성을 입증하기 위해 삶의 만 족, 학교적응, 공격성, 우울과 아동용 기본심리욕구 척도와의 

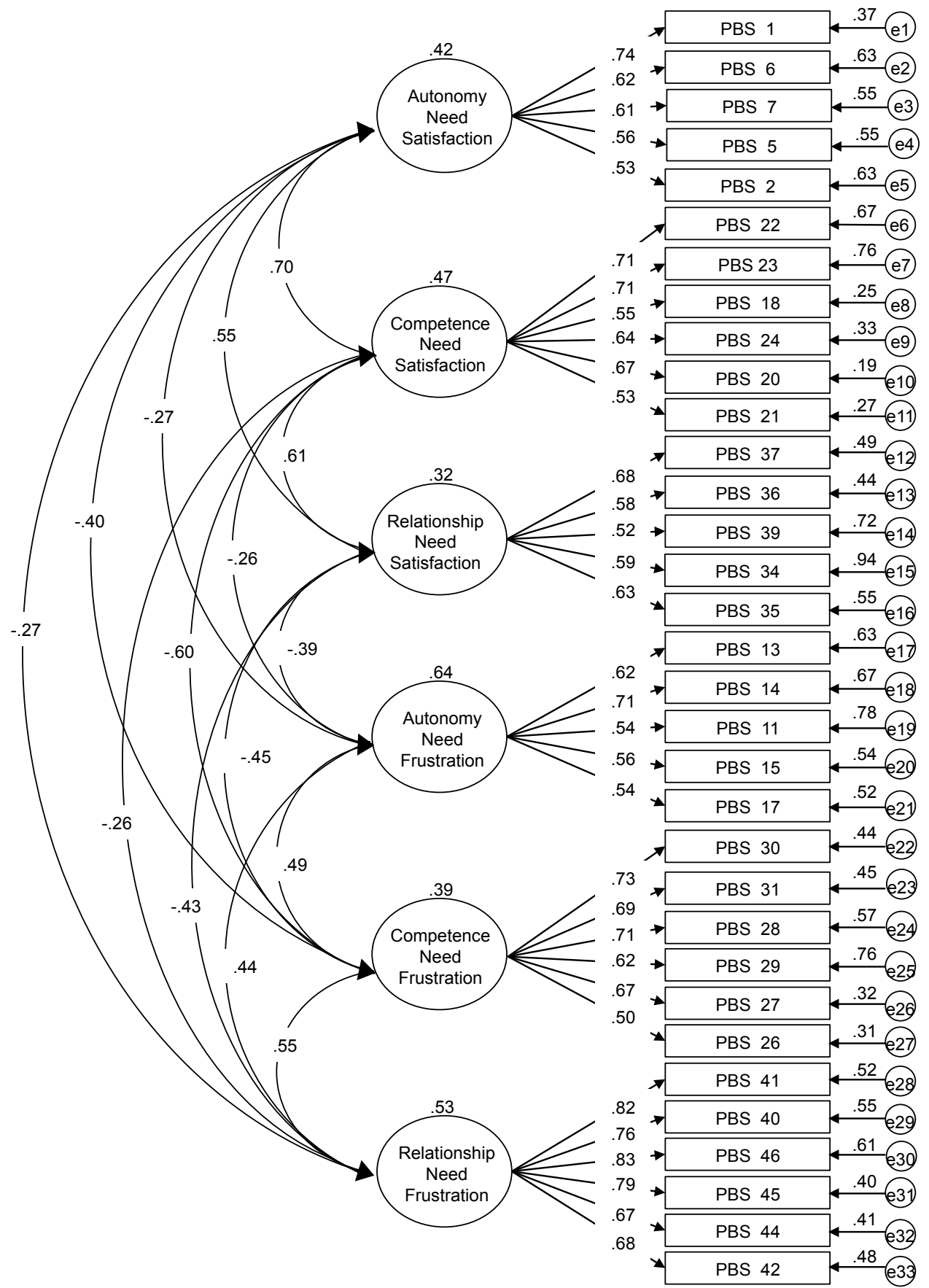

Figure 1. Confirmatory factor analysis of basic psychological needs scale for children.

상관관계를 분석하여 수렴타당도를 살펴보았으며 그 결과는 Table 6, Table 7과 같다.

아동용 기본심리욕구 척도의 각 하위요인과 삶의 만족, 학 교적응, 공격성, 우울과의 상관관계는 모두 유의한 것으로 나 타났다. 이 중 자율성의 욕구만족, 유능성의 욕구만족, 관계성 의 욕구만족은 삶의 만족 $(r=.43 \sim .52, p<.001)$, 학교적응 $(r=$ $.29 \sim .40, p<.001)$ 과는 유의한 정적상관을 공격성 $(r=-.17 \sim$
-.28, $p$ <.001), 우울 $(r=-.28 \sim-.43, p<.001)$ 과는 유의한 부적 상관을 보였다. 반대로 자율성의 욕구좌절, 유능성의 욕구좌 절, 관계성의 욕구좌절은 삶의 만족 $(r=-.35 \sim-.41, p<.001)$, 학교적응 $(r=-.29 \sim-.40, p<.001)$ 과는 유의한 부적상관을 공 격성 $(r=.40 \sim .50, p<.001)$, 우울 $(r=.40 \sim .59, p<.001)$ 과는 유 의한 정적상관을 보였다. 
Table 4

The Reliability and the Sub-Factor Correlation Matrix for the Basic Psychological Needs Scale for Children

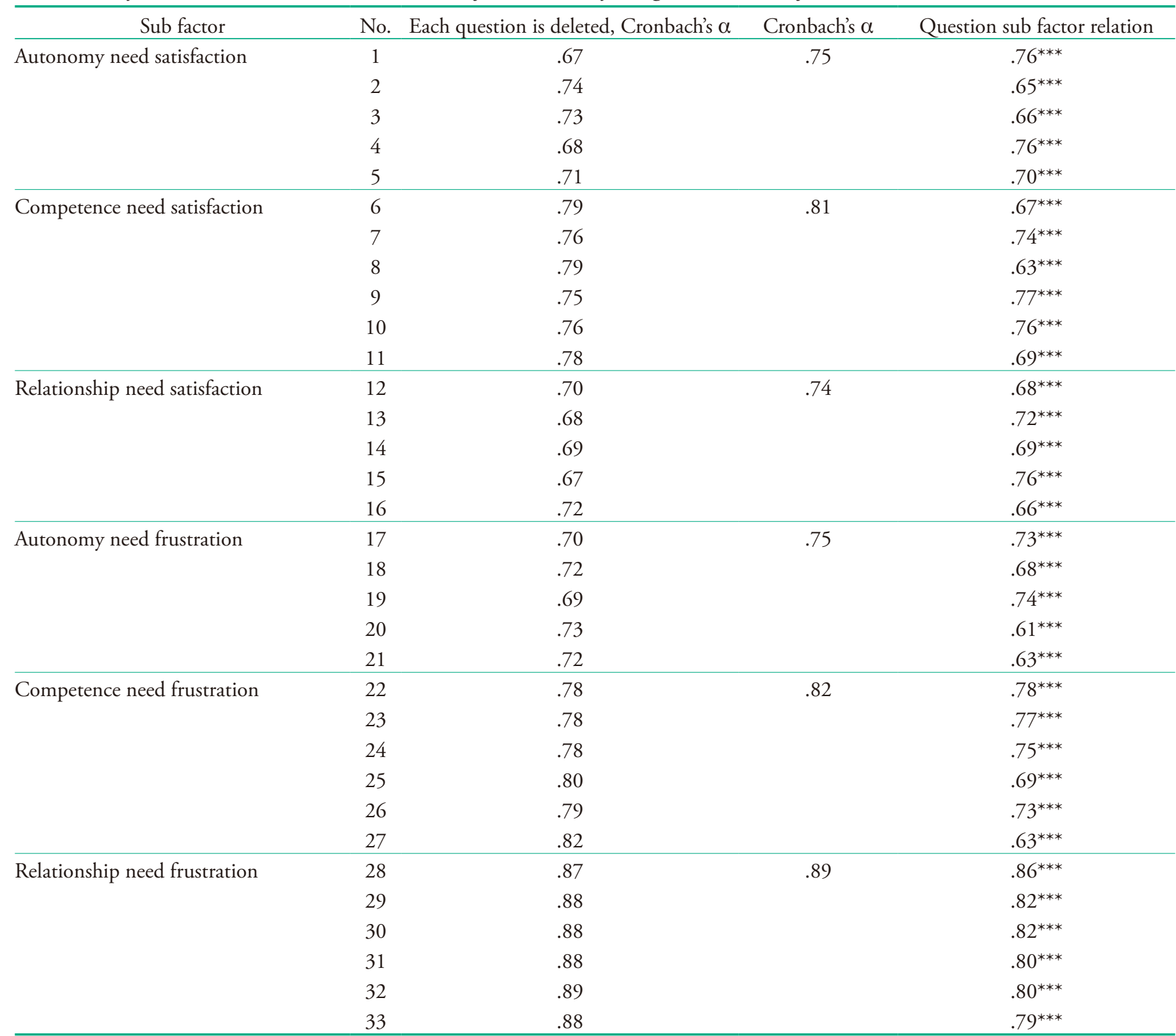

Note. $N=455$.

*** $p<.001$.

\section{변별타당도 검증}

임상아동 집단과 비 임상아동 집단과의 기본심리욕구의 평균 을 비교해 봄으로써 변별타당도를 검증하였다. 임상아동 집단 (34명)과 비 임상아동 집단(34명)의 기본심리욕구 평균을 비 교하기 위해 독립표본 $t$ 검증을 실시하였으며 그 결과는 Table 8 과 같다. 기본심리욕구 만족에 대한 평균을 비교해 보면, 자 율성의 욕구만족, 유능성의 욕구만족, 관계성의 욕구만족 모
두에서 임상아동 집단보다 비 임상아동 집단의 평균이 더 높 은 것으로 나타났으며, 통계적으로 유의한 차이를 보였다 $(t=$ 6.75 9.61, $p$ <.001). 반대로 기본심리욕구 좌절에서는 자율 성의 욕구좌절, 유능성의 욕구좌절, 관계성의 욕구좌절 모두 에서 임상아동 집단의 평균이 비 임상아동 집단의 평균보다 더 높은 것으로 나타났으며, 통계적으로 유의미한 차이를 보 였다 $(t=-8.73 \sim-9.84, p<.001)$. 
Table 5

Final Factors and Item (BPNS-C)

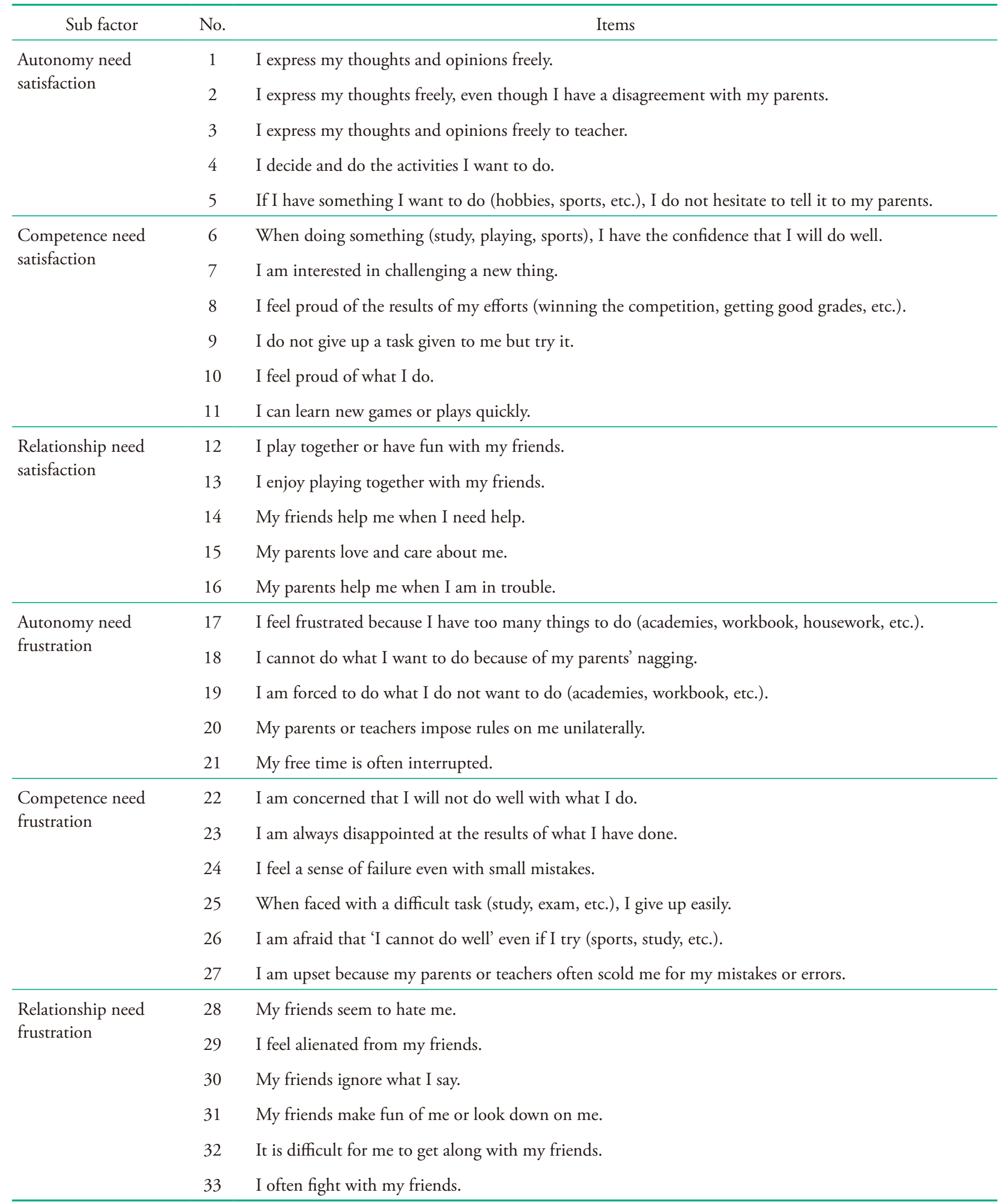


Table 6

Correlation Between Life Satisfaction, School Adjustment, Aggression, Depression and Basic Psychological Needs Satisfaction for Children

\begin{tabular}{lcrc}
\hline & & \multicolumn{2}{c}{ Basic psychological needs satisfaction } \\
\cline { 2 - 4 } & Autonomy need satisfaction & Competence need satisfaction & Relationship need satisfaction \\
\hline Life satisfaction & $.43^{* * *}$ & $.52^{* * *}$ & $.48^{* * *}$ \\
School adjustment & $.29^{* * *}$ & $.36^{* * *}$ & $.40^{* * *}$ \\
Aggression & $-.17^{* * *}$ & $-.28^{* * *}$ & $-.27^{* * *}$ \\
Depression & $-.28^{* * *}$ & $-.43^{* * *}$ & $-.41^{* * *}$ \\
\hline
\end{tabular}

Note. $N=455$.

*** $p<.001$.

Table 7

Correlation Between Life Satisfaction, School Adjustment, Aggression, Depression and Basic Psychological Needs Frustration for Children

\begin{tabular}{lccc}
\hline & & Basic psychological needs frustration \\
\cline { 2 - 4 } & & Competence need frustration & Relationship need frustration \\
\hline Life satisfaction & Autonomy need frustration & $-.35^{* * *}$ & $-.40^{* * *}$ \\
School adjustment & $-.29^{* * *}$ & $-.40^{* * *}$ & $-.41^{* * *}$ \\
Aggression & $.41^{* * *}$ & $.50^{* * *}$ & $.50^{* * *}$ \\
Depression & $.40^{* * *}$ & $.59^{* * *}$ & $.56^{* * *}$ \\
\hline
\end{tabular}

Note. $N=455$.

*** $p<.001$.

Table 8

Average Comparison of Basic Psychological Needs Between Clinical Children and Nonclinical Children

\begin{tabular}{|c|c|c|c|c|}
\hline \multirow{2}{*}{\multicolumn{2}{|c|}{ Sub-factor }} & $\begin{array}{c}\text { Nonclinical child } \\
\quad(n=34)\end{array}$ & $\begin{array}{l}\text { Clinical child } \\
\quad(n=34)\end{array}$ & \multirow[b]{2}{*}{$t$} \\
\hline & & $M(S D)$ & $M(S D)$ & \\
\hline \multirow{2}{*}{ Basic psychological needs satisfaction } & Competence need satisfaction & $4.00(.44)$ & $2.79(.77)$ & $7.99^{* * *}$ \\
\hline & Relationship need satisfaction & $4.47(.45)$ & $2.79(.92)$ & $9.61^{* * *}$ \\
\hline \multirow[t]{4}{*}{ Basic psychological needs frustration } & Autonomy need frustration & $2.54(.64)$ & $3.90(.64)$ & $-8.73^{* * *}$ \\
\hline & Competence need frustration & $2.02(.71)$ & $3.66(.66)$ & $-9.84^{* * *}$ \\
\hline & Relationship need frustration & $1.55(.68)$ & $3.22(.86)$ & $-8.91^{* * *}$ \\
\hline & Basic psychological needs frustration total & $2.02(.29)$ & $3.59(.54)$ & $-14.88^{* * *}$ \\
\hline
\end{tabular}

Note. $N=68$.

*** $p<.001$.

\section{아동용 기본심리욕구 척도의 신뢰도}

본 연구에서 개발한 아동용 기본심리욕구 척도의 신뢰도를 검
증하기 위해 내적합치도와 반분신뢰도를 산출하였으며 그 결 과는 Table 9와 같다. 먼저 Cronbach's $\alpha$ 계수를 산출한 결과 아 동용 기본심리욕구 만족 전체에 있어서는 .86 , 각 하위요인인 
Table 9

Reliability of Basic Psychological Needs Scale for Children (BPNS-C)

\begin{tabular}{llccc}
\hline & Sub factor & Number of questions & Cronbach's $\alpha$ & Split half reliability \\
\hline $\begin{array}{l}\text { Basic psychological } \\
\text { needs satisfaction }\end{array}$ & Autonomy need satisfaction & 5 & .75 & .76 \\
& Competence need satisfaction & 6 & .81 & .74 \\
& Relationship need satisfaction & 5 & .86 & .80 \\
& Basic psychological needs satisfaction total & 16 & .75 & .82 \\
Basic psychological & Autonomy need frustration & 5 & .80 & .89 \\
needs frustration & Competence need frustration & Relationship need frustration & 6 & .80 \\
& Basic psychological needs frustration total & 17 & .91 \\
\hline
\end{tabular}

Note. $N=455$.

자율성, 유능성, 관계성의 욕구만족은 .75, .81, .74로 나타났다. 기본심리욕구 좌절 전체에 있어서는 .88 , 각 하위요인인 자율 성, 유능성, 관계성의 욕구좌절은 $.75, .82, .89$ 로 나타났다. 다 음으로 아동용 기본심리욕구 문항을 반으로 나누어 반분신뢰 도를 산출하였다. 하나의 검사를 양분하는 방법에는 여러 가 지가 있으나 홀수번호 문항과 짝수번호 문항으로 나누는 것이 가장 보편적인 방법이다. 이에 따라 본 연구에서도 홀수번호 문항과 짝수번호 문항으로 나누어 두 집단 간의 상관계수를 구한 후 Spearman-Brown공식에 의해 신뢰도를 산출하였다. 그 결과 기본심리욕구 만족 전체에서는 Spearman-Brown 계수가 .89 , 기본심리욕구 좌절 전체에서는 .91이었으며, 각 하위 요 인별로는 .76 .90으로 높게 나타났다.

\section{Discussion}

본 연구는 초등학교 고학년을 대상으로 기본심리욕구 이론에 근거하여 아동의 기본심리욕구 만족과 좌절을 측정할 수 있는 타당하고 신뢰로운 척도를 개발하는데 목적이 있다. 먼저 아 동용 기본심리욕구 척도의 예비문항을 선정하기 위하여 선행 연구 고찰을 통해 기본심리욕구의 개념과 하위요인의 특성을 파악하였다. 다음으로 초등 4-5학년 아동 23명을 대상으로 개 방형 질문지를 통해 집단면접을 진행한 후 면접 내용을 범주 화하고, 문항 진술문을 구성하였다. 선행연구 고찰과 집단면 접에 근거하여 도출된 예비문항의 적절성을 평가하기 위해 전 문가를 대상으로 2 차에 걸친 델파이 조사를 실시하여 내용타 당도를 검증하였다. 그 결과 자율성의 욕구만족 및 좌절, 유능 성의 욕구만족 및 좌절, 관계성의 욕구만족 및 좌절과 관련된
49개의 예비문항이 선정되었다. 아동용 기본심리욕구 척도의 하위요인과 최종문항을 선정하기 위하여 초등 4-6학년 아동을 대상으로 본조사를 실시한 후 척도의 타당도와 신뢰도를 검증 하였다. 본 연구의 결과를 요약하고 논의하면 다음과 같다.

첫째, 먼저 전체 문항에 대하여 탐색적 요인분석을 실시한 결과 자율성의 욕구만족과 좌절, 유능성의 욕구만족과 좌절, 관계성의 욕구만족과 좌절로 나타나, 기본심리욕구 만족과 좌 절은 서로 구분되는 차원임이 확인되었다. 이에 전체 문항을 만족과 좌절로 다시 나누어 탐색적 요인분석을 재실시한 결 과 자율성의 욕구만족(5문항), 유능성의 욕구만족(6문항), 관 계성의 욕구만족(5문항), 자율성의 욕구좌절(5문항), 유능성 의 욕구좌절(6문항), 관계성의 욕구좌절(6문항) 총 6요인, 33 문항이 선정되었다. 이는 성인을 대상으로 기본심리욕구 만족 및 좌절 척도를 개발하고 타당화한 선행연구(Chen et al., 2015; Nishimura \& Suzuki, 2016)의 구성요인과 일치하는 결과이다.

둘째, 확인적 요인분석에서는 탐색적 요인분석에서 나타 난 결과에 따라 아동용 기본심리욕구의 하위요인을 총 6요인 으로 하여 연구모형의 적합도를 검증하였다. 또한 선행연구 (Chen et al., 2015; J. H. Lee, 2016)를 바탕으로 경쟁모형의 적 합도도 함께 확인하였다. 그 결과 두 가지 측정모형 모두 적합 도 지수가 수용할 만한 수준으로 나타났으나, 6요인인 연구모 형의 적합도 지수가 더 좋은 것으로 확인되었다. 이를 통해 본 연구에서 개발한 아동용 기본심리욕구 척도는 만족과 좌절이 포함된 총 6 개의 요인구조로서 적합한 척도임이 검증되었으 며, 본 연구에서 개발된 척도와 기존척도를 비교하여 논의하 면 다음과 같다.

먼저, 본 연구에서 개발된 기본심리욕구 만족문항들은 선 행연구(Jeon, 2013; K.-H. Kim, 2002; M. Lee, 2008; Ryan \& 
Deci, 2002)에서 개발된 문항의 내용과 유사한 것으로 나타났 다. 자율성의 경우 스스로 선택하고 자유롭게 표현하는 문항 (K.-H. Kim, 2002), 유능성의 경우 자신감과 성취감, 뿌듯함을 느낀다는 문항에서 선행연구(H.-E. Lee, 2012; M. Lee, 2008)와 유사하다. 그러나 국내에서 개발된 기본심리욕구 척도는 만족 에 해당하는 문항들로 구성되어 있어 좌절 문항이 포함된 본 연구와는 차이가 있다. 국외의 경우 만족과 좌절을 포함한 척 도가 개발되었으나 이는 성인을 대상으로 한 연구(Chen et al., 2015)로 아동을 대상으로 한 본 척도와는 차이가 있다.

기본심리욕구 좌절 문항을 살펴보면, 자율성의 욕구좌절은 주로 부모나 학업과 관련하여 좌절을 경험하는 문항들이 포함 되었는데 이는 한국의 부모가 자녀의 일상을 통제하고 개입하 는 경우가 많으며(H. Kim, 2015; M.-J. Lee, 2010), 과외활동의 부담으로 아동이 하고 싶은 일을 충분히 하지 못하기 때문으 로 사료된다. 유능성의 욕구좌절은 부모님이나 선생님으로부 터 실수를 지적받는 문항이 포함되었다. 아동기는 근면성 대 열등감의 시기로, 성인의 반복적인 지적은 아동에게 열등감을 느끼게 할 수 있다. 또한 아동기는 또래와 집단을 형성하는 시 기로 또래의 영향을 많이 받기 때문에 또래관련 문항이 관계 성의 좌절 요인에 많이 포함된 것으로 보인다.

또한 국내에서 개발된 기본심리욕구 척도(Jeon, 2013; H.J. Kim, 2009; M. Lee, 2008)들은 대부분 성인과 청소년을 대상 으로 하였기에 문항의 내용이 구체적이지 못하고 추상적이다. 아동용 척도(H.-E. Lee, 2012) 역시 문항 내용이 다양하지 못하 여 기본심리욕구의 다양한 측면을 반영하는데 한계가 있었다. 그러나 본 연구에서 개발된 척도의 문항은 아동들의 구체적인 경험을 반영하여 아동이 이해하기 쉬운 진술문으로 구성되었 으며, 청소년 척도와 비교해볼 때, 본 척도는 아동기의 발달적 특성이 반영되었다고 볼 수 있다.

셋째, 본 연구에서 개발된 아동용 기본심리욕구 척도의 수 렴타당도를 검증하기 위해 아동용 기본심리욕구 척도와 신체 적·정신적인 건강 및 편안함을 의미하는 웰빙(삶의 만족, 학 교적응), 신체적·정신적인 어려움과 고통을 의미하는 일빙(공 격성, 우울)과의 관계를 분석하였다. 기본심리욕구 만족은 삶 의 만족, 학교적응과 정적상관, 공격성, 우울과 부적상관이 있 는 것으로 나타났으며 이는 기본심리욕구 만족이 높을수록 웰빙 즉, 활력, 긍정정서, 삶의 만족 수준이 높다는 선행연구 (Eryilmaz, 2012; Hong \& Park, 2017; Jeon, 2013; M. N. Kwon \& Lee, 2015; Milyavskaya \& Koestner, 2011)들과 일치한다. 반대 로 기본심리욕구 좌절은 삶의 만족, 학교적응과 부적상관, 공 격성, 우울과 정적상관이 있는 것으로 나타났다. 특히 욕구좌
절은 웰빙 지표인 삶의 만족, 학교적응보다 일빙 지표인 공격 성, 우울과 더 큰 상관이 있는 것으로 나타났다. Chen 등(2015) 은 낮은 욕구만족이 우울, 불안, 소진 등과 같은 일빙을 예측하 는 것이 아니라 욕구좌절이 일빙에 직접적인 영향을 미친다고 보고하여 본 연구와 부분적으로 일치한다고 볼 수 있다.

넷째, 변별타당도를 검증하기 위해 비 임상아동 집단과 임 상아동 집단의 기본심리욕구 평균의 차이를 비교하였다. 그 결과 자율성, 유능성, 관계성의 욕구만족 평균은 임상아동 집 단에 비해 비 임상아동 집단에서 더 높은 것으로 나타났으며, 자율성, 유능성, 관계성의 욕구좌절 평균은 비 임상아동 집단 에 비해 임상아동 집단에서 더 높은 것으로 나타났다. 이는 기 본심리욕구가 만족되지 못하고 좌절될 때 우울, 공격성, 위 축, 비행과 같은 심리적 문제가 발생한다는 기본심리욕구 이 론을 지지하는 결과이다(Chen et al., 2015; Deci \& Ryan, 2000, Vansteenkiste \& Ryan, 2013).

다섯째, 신뢰도를 분석한 결과 기본심리욕구 척도의 각 하위요인별 Cronbach's $\alpha$ 는 .74 .89, 반분신뢰도(SpearmanBrown) 계수는 .76 .90로 나타났다. 신뢰도 계수에 대한 판 단은 학자마다 다르지만 사회과학 분야에서는 일반적으로 Cronbach's $\alpha$ 값이 .70 이상일 때 신뢰할 수 있는 것으로 보며, .80이상일 때 높다고 본다(Hwang, Song, Choi, \& Son, 2008). 이러한 근거에 비추어 볼 때 본 연구에서 개발된 아동용 기본 심리욕구 척도는 신뢰로운 척도임이 확인되었다.

결론적으로 구성타당도, 수렴타당도, 변별타당도 및 신뢰 도 분석을 통해 본 연구에서 개발된 아동용 기본심리욕구 척 도는 타당하고 신뢰로운 도구임이 검증되었으며, 아동의 기본 심리욕구 만족과 좌절을 모두 측정하기에 적합하다고 볼 수 있다. 국내에서 개발된 아동용 기본심리욕구 척도는 만족만을 측정하는 것으로 좌절을 함께 측정할 수 있는 도구가 아직 개 발되지 않은 상황이다. 이러한 시점에서 아동의 실제경험과 아동기 발달적 특성을 반영하여 기본심리욕구 만족 및 좌절을 모두 측정할 수 있는 신뢰롭고 타당한 척도를 개발 하였다는 점에서 의의가 있다.

끝으로 본 연구의 제한점과 후속연구를 위한 제언은 다음 과 같다. 첫째, 본 연구에서는 전라지역의 학생만을 대상으로 연구를 진행하였으므로 후속 연구에서는 광범위한 집단에서 척도의 이론적 구조를 확인하는 연구가 필요할 것이다. 둘째, 본 연구에서 개발한 아동용 기본심리욕구 척도의 설명력을 살 펴볼 때 기본심리욕구 만족의 경우 $42 \%$, 좌절의 경우 $45 \%$ 로 만족과 좌절에 해당하는 각 요인의 설명력이 상대적으로 높지 않다는 점이 한계점이라고 볼 수 있다. 척도의 설명력을 높일 
수 있는 추후 연구가 필요하다고 보여진다. 셋째, 본 연구에서 는 기본심리욕구의 만족과 좌절이 서로 다른 차원으로 구분되 었으나 이를 경험적으로 입증하는데 한계가 있다. 추후 기본 심리욕구의 만족과 좌절에 대한 경험적 연구들을 통해 욕구만 족과 좌절이 웰빙 및 일빙과의 관계에서 서로 다른 역할을 하 는지 규명되어야 할 것으로 보인다. 넷째, 본 연구에서는 부모 나 교사의 객관적 평가가 필요한 '공격성'척도를 아동이 직접 응답하도록 하였다. 후속 연구에서는 공격성을 객관적으로 평 가한 자료를 사용하거나, 주관적 평가가 가능한 '분노'와 같은 변인을 선정하여 기본심리욕구 좌절과의 관계를 살펴볼 필요 가 있다. 다섯째, 본 연구에서는 검사-재검사 신뢰도를 산출하 지 못하여 척도의 안정성을 검증하는데 어려움이 있다. 후속 연구에서는 일정 시간 간격을 두고 동일한 대상을 통해 검사 를 반복하여 척도의 안정성을 확인할 필요가 있다.

\section{Notes}

This article is a part of the first author's doctoral dissertation submitted in 2018, and was presented as a verbal announcement at the 2018 Annual Fall Conference of the Korean Association of Child Studies.

\section{Conflict of Interest}

No potential conflict of interest relevant to this article was reported.

\section{Ethics Statement}

All procedures of this research were reviewed by IRB (JBNU 201701-010-005).

\section{References}

\section{In English}

Adie, J. W., Duda, J. L., \& Ntoumanis, N. (2012). Perceived coach-autonomy support, basic need satisfaction and the well and ill-being of elite youth soccer players: A longitudinal investigation. Psychology of Sport and Exercise, 13(1), 51-59. doi:10.1016/j.psychsport.2011.07.008

Bartholomew, K. J., Ntoumanis, N., Ryan, R. M., Bosch, J. A., \& Thøgersen-Ntoumani, C. (2011). Self-determination theory and diminished functioning: The role of interpersonal control and psychological need thwarting. Personality and Social Psychology Bulletin, 37(11), 14591473. doi:10.1177/0146167211413125

Bartholomew, K. J., Ntoumanis, N., Ryan, R. M., \& ThøgersonNtoumani, C. (2011). Psychological need thwarting in the sport context: Assessing the darker side of athletic experience. Journal of Sport \& Exercise Psychology, 33(1), 75102. doi:10.1123/jsep.33.1.75

Chen, B., Vansteenkiste, M., Beyers, W., Boone, L., Deci, E. L., Van der Kaap-Deeder, J., . . .Verstuyf, J. (2015). Basic psychological need satisfaction, need frustration, and need strength across four cultures. Motivation and Emotion, 39(2), 216-236. doi:10.1007/s11031-014-9450-1

Deci, E. L., \& Ryan, R. M. (2000). The "what" and "why" of goal pursuits: Human needs and the self-determination of behavior. Psychological Inquiry, 11(4), 227-268. doi:10.1207/ S15327965PLI1104_01

Erikson, E. H. (1982). The life cycle completed: A review. New York: W. W. Norton.

Eryilmaz, A. (2012). A model for subjective well-being in adolescence: Need satisfaction and reasons for living. Social Indicators Research, 107(3), 561-574. doi:10.1007/s11205011-9863-0

Gagné, M., \& Deci, E. L. (2005). Self-determination theory and work motivation. Journal of Organizational Behavior, 26(4), 331-362. doi:10.1002/job.322

Huebner, E. S. (1991). Initial development of the student's life satisfaction scale. School Psychology International, 12(3), 231-240. doi:10.1177/0143034391123010

Milyavskaya, M., \& Koestner, R. (2011). Psychological needs, motivation, and well-being: A test of self-determination theory across multiple domains. Personality and Individual Differences, 50(3), 387-391. doi:10.1016/j.paid.2010.10.029

Nishimura, T., \& Suzuki, T. (2016). Basic psychological need satisfaction and frustration in Japan: Controlling for the big five personality traits. Japanese Psychological Research, 58(4), 320-331. doi:10.1111/jpr.12131

Ryan, R. M., \& Deci, E. L. (2000). Intrinsic and extrinsic motivations: Classic definitions and new directions. Contemporary Educational Psychology, 25(1), 54-67. doi:10.1006/ceps.1999. 1020

Ryan, R. M., \& Deci, E. L. (2002). Overview of self-determination theory: An organismic dialectical perspective. In E. L. Deci \& R. M. Ryan (Eds.), Handbook of self-determination research (pp.3-36). Rochester, NY: University of Rochester Press. 
Tian, L., Chen, H., \& Huebner, E. S. (2014). The Longitudinal relationships between basic psychological needs satisfaction at school and school-related subjective well-being in adolescents. Social Indicators Research, 119(1), 353-372. doi:10.1007/ s11205-013-0495-4

Vansteenkiste, M., \& Ryan, R. M. (2013). On psychological growth and vulnerability: Basic psychological need satisfaction and need frustration as a unifying principle. Journal of Psychotherapy Integration, 23(3), 263-280. doi: $10.1037 / \mathrm{a} 0032359$

Vansteenkiste, M., Ryan, R. M., \& Deci, E. L. (2008). Self-determination theory and the explanatory role of psychological needs in human well-being. In L. Bruni, F. Comim, \& M. Pugno (Eds.), Capabilities and Happiness (pp.187-223). New York: Oxford University Press.

\section{In Korean}

Cho, B.-H., \& Lim, K.-H. (2003). Development and validation of emotional or behavioral problems scale. The Korean Journal of Counseling and Psychotherapy, 15(4), 729-746.

Cho, H. M. (2014). The relationships among basic psychological needs, achievement goal-orientation, school happiness and academic achievement of elementary school students (Master's thesis). Retrieved from http://www.riss.kr/link?id=T13523208

Cho, S. (2014). Development and validation of the school adjustment scale for school-aged children (Doctoral dissertation). Retrieved from http://www.riss.kr/link?id=T13522341

Choi, I. (2007). Development and validation study of the korean version of parent-child relationship instrument. The Korea Journal of Youth Counseling, 15(2), 45-56.

Choi, M.-H. (2009). The development and verification of the measurement of children's basic psychological needs on the primary school. Korean Journal of Sport Psychology, 20(4), 87-100.

Hwang, H., Song, Y., Choi, H., \& Son, W. (2008). Yeongyua adongyeongueseoui SPSS jaryobunseok [영유아.아동연구에 서의 SPSS 자료분석]. Seoul: Changjisa.

Heo, E.-J., \& Oh, I. (2014). The relationship between basic psychological needs and hope on adolescents' school adjustment. Journal of Educational Studies, 45(3), 137-165. doi:10.15854/ jes.2014.09.45.3.137

Hong, S., \& Park, S. Y. (2017). Autonomy and relatedness satisfaction predicting psychological well-being of adolescents: Focusing on individualism-collectivism cultural values. Korean Journal of Child Studies, 38(2), 5-16. doi:10.5723/kjcs.2017.38.2.5

Jeon, S. H. (2013). Validation of the Korean adolescent's basic psychological need scale (Doctoral dissertation). Retrieved from http://www.riss.kr/link?id=T13368436

Jeong, G.-Y., \& Shin, H.-C. (2010). Development and validation of the basic psychological needs satisfaction scale in mother-child relationships for korean children. The Korean Journal of Counseling and Psychotherapy, 22(3), 753-775.

Jeong, O. (2016). Baldalsimnihak: jeonsaengae inganbaldal [발달심 리학: 전생애 인간발달]. Seoul: Hakjisa.

Kim, A., \& Lee, M.-H. (2008). Structural relationships among adolescents' psychological need satisfaction, depressive tendency, and school adjustment in middle- and highschool. The Korean Journal of Educational Psychology, 22(2), 423-441.

Kim, H. (2015). A study on effect of the familism values on the caregiving stress: Focused on adult offspring in Korea and China (Doctoral dissertation). Retrieved from http://www.riss.kr/ link?id=T13764260

Kim, H.-J. (2009). A study of factors explaining adolescents' wellbeing by developing parent-adolescent communication and basic psychological needs scales (Doctoral dissertation). Retrieved from http://www.riss.kr/link?id=T11983082

Kim, I.-S. (2009). Validation of the basic psychological needs scale for elementary school children. The Korean Journal of the Elementary Physical Education, 15(2), 1-13.

Kim, K.-H. (2002). The effect of self-control training on the elementary school children's autonomy (Master's thesis). Retrieved from http://www.riss.kr/link?id=T8373721

Kim, S.-S. (2006). Analyst of the cause of well-being culture and groping for the desirable way of it-In relation to body(psyche), image, and unconsciousness. Journal of KNU Institute of East-West Thought, 1, 113-140.

Kim, J., Kim, M., \& Hong, S. (2012). Gujobangjeongsingmohyeongeuro nonmun sseugi [구조방정식모형으로 논문 쓰기]. Seoul: Communication Books.

Kwon, J. (2016). A study of path evolution of policies on private education in South Korea (Doctoral dissertation). Retrieved from http://www.riss.kr/link?id=T14198462

Kwon, M. N., \& Lee, J. S. (2015). The relationships among parenting behavior, basic psychological needs and happiness perceived by school children. Journal of Korean Council for Children \& Rights, 19(4), 589-610.

Kwon, S.-H., \& Kim, J. (2014). Relations between basic psychological needs satisfaction, daily stress, and wellbeing in children. The Journal of the Korean Association of Psychotherapy, 6(1), 1-15.

Lee, H.-E. (2012). A structural analysis on school-aged children's well-being and its related variables (Doctoral dissertation). Retrieved from http://www.riss.kr/link?id=T12676387

Lee, J. H. (2016). The validation study of the korean version of basic psychology need satisfaction and frustration scale (Master's thesis). Retrieved from http://www.riss.kr/link?id=T14517509

Lee, M. (2008). A study in the development and the construct validity of a basic psychological need scale base on self-determination theory (SDT) for Korean (Master's thesis). Retrieved from 
http://www.riss.kr/link?id=T11209976

Lee, M.-J. (2010). Parental control and children's autonomy as related to children's self-esteem (Master's thesis). Retrieved from http://www.riss.kr/link?id=T12115190

Lee, M.-K., \& Kim, S.-H. (2011). Development of a parentchild relationships s cale for upper grade elementary school students. Korea Journal of Counseling, 12(3), 997-1017.

Lee, S. A. (2016). Effects of parent-child attachment on selfdiscrepancy \& peer relations of school-aged children (Master's thesis). Retrieved from http://www.riss.kr/link?id= T14010731

Lee, S. Y. (2012). The mediating effects of the basic psychological needs in the relationships between the perceived parenting attitudes and the school adjustment of the secondary school students (Master's thesis). Retrieved from http://www.riss.kr/link?id= T13054391

Moon, H., Kim, J., Seong, M., Son, S., An, S., \& Jang, Y. (2015). Theory of mental health. Seoul: Changjisa.

National Youth Policy Institute. (2015). KCYPS 1-7th survey code book. Retrieved from http://www.nypi.re.kr

Park, G. (2000). Dachawoncheokdobeop [다차원척도법]. Seoul:
Kyoyookbook.

Sim, H. R. (2016). A single case study of art therapy on self-efficacy of early school age child (Master's thesis). Retrieved from http:// www.riss.kr/link?id=T14138453

Song, J., Ahn, Y., \& Jung, E. (2014). The structural relationship among classroom quality, basic psychological needs, classroom engagement, academic achievement perceived by elementary school students. The Korea Journal of Education Psychology, 28(1), 179-203.

\section{ORCID}

Mi Na Kwon http://orcid.org/0000-0003-3824-3027

Jinsuk Lee http://orcid.org/0000-0003-2681-0979

Received February 28, 2019

Revision received March 30, 2019

Accepted April 12, 2019 